\title{
Effects of an incremental walking test in the gait of individuals with Chronic Obstructive Pulmonary Disease
}

\author{
Efeitos de um teste incremental de caminhada na marcha de individuos \\ com Doença Pulmonar Obstrutiva Crônica
Efectos de un test adicional de caminada en la marcha de individuos con Enfermedad Pulmonar Obstructiva Crónica

Cecília Rossatto Facco', Juliana Corrêa Soares', Carlos Bolli Mota², Maria Elaine Trevisan ${ }^{3}$

\begin{abstract}
I The objective of this study was to evaluate the functionality of gait and cardiorespiratory parameters in individuals with chronic obstructive pulmonary disease (COPD), before and after a walk test, in order to allow the development of strategies, aimed at maintaining autonomy and preservation of independence. In this study, were included individuals with COPD, aged between 50 to 80 years, and excluded those with orthopedic, neurological and cardiac problems, or any condition that would prevent the assessments proposed in this study. The variables measured were: $1^{\text {st }}$ peak force, mid peak low and $2^{\text {nd }}$ peak force, time of $1^{\text {st }}$ double support, the swing moment and $2^{\text {nd }}$ double support; single support time, stride length and stride, speed and time gait cycle, heart rate, oxygen saturation and dyspnea/tiredness score, pre and post-test. The sample consisted of 14 individuals (8 females and 6 males), mean age $65.21 \pm 9.42$ years. In the post-test patients had greater sensation of dyspnea / fatigue, increased speed and reduced time of the gait cycle, increase the $1^{\text {st }}$ peak force and reduction of the mid peak low, reduction the time the $1^{\text {st }}$ double support and the time of the $1^{\text {st }}$ peak force. The physical effort had influenced the gait pattern and cardiorespiratory parameters in this group of individuals with COPD.
\end{abstract}

Keywords I Pulmonary Disease, Chronic Obstructive; Gait; Dyspnea
RESUMO I O objetivo do estudo foi avaliar o padrão da marcha e os parâmetros cardiorrespiratórios em indivíduos com doença pulmonar obstrutiva crônica (DPOC), antes e após um teste de caminhada, para permitir o desenvolvimento de estratégias visando à manutenção da autonomia e preservação da independência. Foram incluídos indivíduos com DPOC, com idade entre 50 e 80 anos, e excluídos os com problemas ortopédicos, neurológicos, cardíacos, ou qualquer condição que inviabilizasse as avaliações propostas neste estudo. As variáveis aferidas foram: 10 pico de força, vale e $2^{\circ}$ pico de força; tempo do 10 duplo apoio, da fase de balanço e do $2^{\circ}$ duplo apoio; tempo de apoio simples, comprimento do passo e da passada, velocidade e tempo do ciclo da marcha, frequência cardíaca, saturação periférica de oxigênio e escore dispneia/cansaço, nos períodos pré e pós-teste. A amostra foi constituída por 14 indivíduos (8 do sexo feminino e 6 do sexo masculino), média de idade de 65,21ะ9,42 anos. No pós-teste os indivíduos apresentaram maior sensação de dispneia/cansaço; aumento da velocidade e redução do tempo do ciclo da marcha; aumento do 10 pico de força e redução do vale; redução do tempo do 10 duplo apoio e do tempo do 10 pico de força. O esforço físico influenciou o padrão de marcha e os parâmetros cardiorrespiratórios neste grupo de indivíduos com DPOC.

Descritores I Doença Pulmonar Obstrutiva Crônica; Marcha; Dispneia.

Study conducted at the Biomechanics Laboratory of the Federal University of Santa Maria (UFSM) - Santa Maria (RS), Brazil. 'Biomechanics Laboratory at the UFSM - Santa Maria (RS), Brazil.

2Department of Sports Techniques and Methods of the Center of Physical Education and Sports at the UFSM - Santa Maria (RS), Brazil. ${ }^{3}$ Department of Physiotherapy and Rehabilitation at the UFSM - Santa Maria (RS), Brazil. 
RESUMEN I El objetivo del estudio fue evaluar el patrón de la marcha y los parámetros cardiorrespiratorios en individuos con enfermedad pulmonar obstructiva crónica (EPOC), antes y después de un test de caminada, para permitir el desarrollo de estrategias orientadas a mantener preservación de su autonomía e independencia. Fueron incluidos individuos con EPOC, de edades entre 50 y 80 años, y excluidos los que presentaban problemas ortopédicos, neurológicos, cardíacos, o cualquier condición que impidiera las evaluaciones propuestas en este estudio. Las variables medidas fueron: 10 pico de fuerza, valle y $2^{\circ}$ pico de fuerza; el tiempo del 10 doble apoyo, de la fase de balanceo y del segundo doble apoyo; tiempo de apoyo simple, longitud del paso y pasada, velocidad y tiempo de ciclo de la marcha, la frecuencia cardíaca, saturación periférica de oxígeno y puntuación de la disnea/fatiga, antes y después del test. La muestra fue constituida en 14 individuos (8 del sexo femenino y 6 masculino), promedio de edad de 65,21+9,42 años. En el postest los individuos presentaron mayor sensación de disnea/ fatiga, aumento de la velocidad y reducción del tiempo del ciclo de la marcha; aumentó del 10 pico de fuerza y la reducción del valle; reducción del tiempo del 10 doble apoyo y del tiempo del 10 pico de fuerza. El esfuerzo físico influyó el patrón de la marcha y los parámetros cardiorrespiratorios en este grupo de individuos con EPOC.

Palabras clave I Enfermedad Pulmonar Obstructiva Crónica; Marcha; Disnea.

\section{INTRODUCTION}

The Chronic Obstructive Pulmonary Disease (COPD) is a preventable and treatable disease with some significant extra pulmonary effects that may contribute individually to the severity, as defined by the consensus of the World Health Organization - Global Initiative for Chronic Obstructive Lung Disease ${ }^{1}$.

The prevalence of COPD increases gradually with age, being the leading cause of morbidity in the elderly ${ }^{2}$. As a result of the ageing population, the prevalence of COPD will continue to grow in the coming decades, resulting in a large economic impact ${ }^{2-4}$.

In addition to pulmonary components, systemic consequences are often observed in patients with COPD, such as weight loss, malnutrition, emotional problems, muscle weakness and physical deconditioning ${ }^{2-8}$.

The ability of functional independence seems to depend on the maintenance of flexibility, muscular strength and endurance, features that, as a whole, could be considered as components of muscular fitness. Authors suggest that the gait is a good, if not the best indicator of the risk of loss of autonomy ${ }^{8,9}$.

The human gait comprises a sequence of rapid and complex events, being difficult, by clinical observation, to analyze these phenomena and quantify the degree of departure from normality ${ }^{10,11}$. In order that the ambulation is efficient, three fundamental properties are required: support stability, appropriate means of progression and methods to conserve energy ${ }^{12}$. Everyone has a particular gait pattern to move in the environment with the minimum possible effort, adequate stability and acceptable appearance ${ }^{10}$.

The ground reaction force (GRF) is a force exerted by the ground on a body in contact with it, representing a response to muscle action and body weight transmitted through the feet. It has the same magnitude and direction, but opposite direction to the force that the body exerts on the ground surface ${ }^{13}$. It is a variable that contains quantitative information on gait characteristics, which reflect the effects of internal and external forces during locomotion and enable the identification of changes in the movement pattern ${ }^{13}$.

For evaluation of the functional capacity in patients with different pathologies, the literature points out the use of walking tests, being the Shuttle Walking Test (SWT), an alternative that meets the basic criteria for a stress test for patients with chronic airway obstruction ${ }^{14}$.

It is based on a family activity, unlike the cycle ergometer or treadmill, and has the advantage of being normalized, with controlled speed and imposing a progressive effort ${ }^{15,16}$.

The clinical gait analysis is of great importance to the therapeutic planning of different neuromuscular pathologies and musculoskeletal disorders, such as cerebral palsy and in the case of lower limb amputations ${ }^{11}$. The knowledge of the functional characteristics and the influence of stress on the gait of individuals with COPD may allow the development of specific rehabilitation strategies to maintain the autonomy and preserve independence, for as long as possible $\mathrm{e}^{8,9,12,17}$.

Studies, which have assessed the gait pattern in COPD with the methodological approach of the current research, were not found in the literature. A systematic study, with this research focus, can contribute in the evaluation and clinical practice of these individuals.

From the above, this study aims to evaluate the gait pattern and cardiorespiratory parameters of individuals with COPD, before and after a walking test with progressive loading. 


\section{METHODOLOGY}

This is a convenient and transversal observational study, descriptive type, with quantitative analysis of data.

The study group was composed of individuals of both sexes, aged between 50 and 80 years, with clinical diagnosis of COPD, who attended the local Physiotherapy Service of the Basic Health Unit. Smokers and/or patients with comorbidities, limiting the performance of the activities proposed in the study, such as orthopedic, neurological or cardiac diseases, and tracheostomized patients in oxygen therapy, were excluded. The research protocol was approved by the Research Ethics Committee of the local institution (CAAE 0256.0.243.000-10) and the acceptance confirmed by signing the Informed Consent Form. The sample calculation was estimated for obtaining a level of significance (alpha) of $5 \%(\mathrm{p}<0.05)$ and power (beta) of $80 \%$. For the calculation, the result related to the percentage of the second peak of the ground reaction force during the gait was considered, for being the variable that showed the highest standard deviation (SD 15.84) in the pilot study that served as a reference for this study. The WinPepi program version 10.5 was used, and according to the calculation, the prediction was of a sample of 14 individuals.

Initially, anthropometric and identification data were obtained. Then, with the participant sitting down, the heart rate $(\mathrm{HR})$ and peripheral oxygen saturation $\left(\mathrm{SpO}_{2}\right)$ by fingertip pulse oximeter, and the level of dyspnea/fatigue by Borg scale were obtained at rest. Participants were instructed on collection procedures and should be wearing shorts and sports footwear.

For measuring the gait speed, two TRON photocells, with a distance of $5 \mathrm{~m}$ between them, were used. From the time used to walk between the two photocells, the gait speed was determined. Strips were placed on the floor to mark the path of $5 \mathrm{~m}$ along with $3 \mathrm{~m}$ more at the beginning and end to enable the acceleration and deceleration. The participant received instructions to walk with its usual speed.

For the acquisition of kinetic data regarding GRF, two AMTI OR6-6-2000 (Advanced Mechanical Technologies, Inc.) force plates, $5 \mathrm{~mm}$ apart from each other, with sampling rate of $1000 \mathrm{~Hz}$, were used. The variables analyzed included: First peak force, trough and second peak force, and the relationship of these variables with the duration of the gait cycle. The first peak force represents the initial contact of the foot with the force plate, and is related to the first double support of the gait cycle; the trough occurs when the foot is in the flat position on the ground, and refers to the swing phase of the contralateral foot; and the second peak is related to the withdrawal of the foot from the force plate, i.e. represents the forward forefoot propulsion to start the next $\operatorname{step}^{13}$. The information from the force plate was handled in a routine developed in the Interactive Data Language (IDL) environment to filter data and eliminate possible environmental interferences. A 4th order Butterworth low-pass filter at $75 \mathrm{~Hz}$ frequency was used.

For the kinematic gait assessment, they used the VICON system (model 624, Oxford, United Kingdom), with the software VICON NEXUS 1.5.2 for obtaining and processing data. Seven MX cameras sensitive to infrared, operating at a frequency of $100 \mathrm{~Hz}$, were used The participants were marked on 20 anatomical landmarks, with $14 \mathrm{~mm}$ diameter reflective markers, using the xplug in gait model (pelvis, thigh, leg and foot, on both sides). Using these landmarks, it was possible to obtain speed and displacement measurements of the segments and joints. The kinematic variables analyzed included: first double support time, swing phase time, second double support time, single support time, cycle time and gait speed, step length and stride length. A $4^{\text {th }}$ order and $8 \mathrm{~Hz}$ cutoff frequency Butterworth low-pass filter was used.

The incremental SWT ${ }^{14}$ was conducted subsequent to the initial assessment. It consisted of 12 levels of consecutive walks on a flat route of $20 \mathrm{~m}$ round trip, in increasing speed. The distance was set by two cones half a meter from the end of each route. The increase in speed was determined by the number of back-and-forth cycles in a minute: the first walk was $30 \mathrm{~m}(0.5 \mathrm{~m} / \mathrm{s}$ speed), in the last walk, the participant should make seven round trips in a minute $(2.33 \mathrm{~m} / \mathrm{s}$ speed). A beep indicated when the participant would be close to the cone and change direction. The participants were told to walk until they feel they would not be able to maintain the required speed, i.e. be three meters before the cone when the beep was sounded ${ }^{14}$. The total distance (in meters) walked by the participant was calculated. Soon after the walk test, the $\mathrm{HR}, \mathrm{SpO}_{2}$ and perception of dyspnea/effort were monitored. Immediately at the end of the walk, the gait was reassessed. The evaluators were blinded to the outcome of the study.

The data were submitted to descriptive statistics, with values on average and standard deviation, and analytical statistics. To check the normality of the data, the Shapiro Wilk test was used. In the 
comparison between groups, the T-Student test was used for dependent samples for normal distribution data, and the Wilcoxon test was used for non-normal distribution data. The significance level used for all tests was $5 \%(\alpha=0.05)$.

\section{RESULTS}

The study group was composed of 14 individuals ( 8 females and 6 males), aged between 52 and 78 years (mean 65.21 \pm 9.42 ) and BMI between 20 and $33 \mathrm{~kg} / \mathrm{m}^{2}$ (mean 25.29 \pm 4.11 ). The participants performed two consecutive gait cycles (right and left), and since there was no significant difference in the comparison between the two cycles in the variables studied, we decided to work with the average between cycles. In the spatial variables "step length" and "stride length", a significant difference between the pre and post-test was not verified.

Table 1. Speed and gait cycle time in pre and post-test of walking

\begin{tabular}{lccc} 
& Pre & Post & \\
\cline { 2 - 3 } Variables & mean \pm SD & mean $\pm S D$ & p-value \\
Cycle time & $1.37 \pm 0.25$ & $1.20 \pm 0.19$ & $0.000^{*}$ \\
Gait speed $(\mathrm{m} / \mathrm{s})$ & $0.90 \pm 0.24$ & $1.07 \pm 0.25$ & $0.002^{*}$
\end{tabular}

SD: standard deviation; *Wilcoxon, $\mathrm{p}<0.05$

Table 2. Variables of the ground reaction force curve during gait

\begin{tabular}{lccc}
\multirow{2}{*}{ Variables } & \multicolumn{1}{c}{ Pre } & Post & \\
\cline { 2 - 3 } & mean \pm SD & mean \pm SD & \\
First peak (\%) & $96.37 \pm 14.14$ & $100.84 \pm 15.57$ & $0.017^{*}$ \\
Trough (\%) & $84.79 \pm 14.54$ & $76.53 \pm 13.40$ & $0.000^{*}$ \\
Second peak (\%) & $100.07 \pm 15.51$ & $104.04 \pm 15.84$ & $0.043^{*}$
\end{tabular}

Data normalized by the participant's weight; * Wilcoxon, p<0.05; SD: standard deviation

Table 3. List of gait phases with the gait cycle duration

\begin{tabular}{lccc}
\multirow{2}{*}{ Variables } & Pre & Post & \\
\cline { 2 - 3 } & mean \pm SD & mean \pm SD & p-value \\
First double support (\%) & $13.89 \pm 2.77$ & $12.83 \pm 2.07$ & $0.013^{*}$ \\
Balance (\%) & $36.75 \pm 3.09$ & $37.59 \pm 2.64$ & 0.240 \\
Second double support (\%) & $13.13 \pm 2.87$ & $12.64 \pm 2.56$ & 0.376 \\
Single support & $36.24 \pm 2.64$ & $36.94 \pm 2.44$ & 0.130
\end{tabular}

SD: standard deviation; *Student's $t$ test for dependent samples, $p<0.05$

Table 4. Ground reaction force curve in relation to the gait cycle duration

\begin{tabular}{lccc} 
Variables (\%) & Pre & Post & \\
\cline { 2 - 3 } & mean \pm SD & mean \pm SD & \\
First peak & $27.21 \pm 7.38$ & $24.70 \pm 6.48$ & $0.012^{*}$ \\
Trough & $44.26 \pm 10.53$ & $46.25 \pm 9.79$ & 0.116 \\
Second peak & $74.28 \pm 13.78$ & $72.82 \pm 14.29$ & 0.206
\end{tabular}

SD: standard deviation; data normalized by the participant's weight; * Wilcoxon, $\mathrm{p}<0.05$
Regarding the sensation of dyspnea/fatigue reported by participants, an increase in the dyspnea score at the post-test (mean $3.07 \pm 1.82$ ) when compared to rest (mean $0.5 \pm 0.73$ ) was noted.

With regard to the variables "cycle time" and "gait velocity", a significant increase in speed after the walk test was noted and, consequently, a significant reduction of the gait cycle time (Table 1).

The GRF-related data were normalized by the participant's weight, and are presented in Table 2, in percentage values. At the post-test, there was a significant increase of the first peak force and significant trough reduction of the force used.

The gait cycle phases are shown in percentages in relation to the gait cycle length (Table 3 ).

In Tabela 4, there are the GRF data in accordance with the time percentage when they occurred during the gait cycle. It is evidenced that, at the posttest, the time of the first peak force demonstrated a significant reduction, characterizing the advance of the event, decreasing the damping time of the foot's impact on the ground.

\section{DISCUSSION}

The study aimed to evaluate the gait pattern and cardiorespiratory parameters of individuals with chronic obstructive pulmonary disease, before and after a walking test with progressive loading. It consisted of 14 individuals who, during the post-test, presented more sensation of dyspnea/fatigue; speed increase and reduction of the gait cycle time; increase of the first peak force and reduction of the trough; reduction of the first double support time and first peak force time.

After exposing individuals with COPD to an incremental test, we observed increased sensation of dyspnea and reduction in $\mathrm{SpO}_{2}$.

Pessoa et al. ${ }^{18}$ investigated the cardiovascular and metabolic-ventilatory responses in COPD during the performance of submaximal tests, and also observed desaturation in all tests performed. The study of Dourado et al. ${ }^{2}$ noted that the $\mathrm{SpO}_{2}$ had a negative correlation with the physical activity field, suggesting that hypoxemic patients have minor physical performance capacity.

Cordoni et al..$^{19}$ also found increased dyspnea score after stress test and attributed this condition to the 
movement of the arms, which causes the intercostal inspiratory muscles contribute less to respiratory mechanics, because they are actively participating in the support of the arms and trunk. The abdominal muscles also aid in stabilizing the trunk, being less efficient in expiratory lung emptying and, as a result, less efficient gas exchange and a worsening of ventilation/perfusion mismatching.

There are evidences that the cardiorespiratory changes can result in increased execution speed of the gait. Our results showed that, during the post-test, individuals presented more gait speed and reduction in cycle time, performing the route in less time. It is believed that the increased speed can be a result of the compensatory postural pattern adopted by these individuals characterized by the anterior tilt of the trunk. The pendulum movement of the center of gravity, which characterizes the gait in the terrestrial environment, is modified in COPD, as well as in aging, causing the body to adopt differentiated angular positions to compensate for the change in the projection of the center of gravity and facilitate the increase of the muscle work, which generates the impulse of the foot and moves the body forward ${ }^{8}$.

Ribeiro et al. ${ }^{8}$ observed correlation between gait speed and respiratory muscle strength, suggesting that the possibility of dyspnea during a physical activity leads the individual to perform the gait more quickly and with changes in step length, aiming at greater stability and less time and effort.

Yentes et al. ${ }^{20}$ found significant correlation between the presence of abnormality in gait and physical activity with severe COPD, suggesting that the gait changes may be due to physical inactivity that is present in patients with COPD.

The speed is one of the factors that can change the GRF standard. Cook et al. ${ }^{21}$ assert that the speed influence on GRF can elevate the first peak of the vertical force in relation to the second peak. Perry ${ }^{22}$ confirms that at higher speeds, there are higher and less durable vertical peak forces, and larger troughs on vertical GRF. In this study, we highlight the reduction in the duration and GRF increase in the first peak force.

The fact of the speed adopted by the participants of this study during the post-test has been greater than those speeds observed in the pre-test can be attributed to the weakness of the peripheral muscles of COPD and consequent fatigue, so as to try to recover its center of gravity and not lose the balance during the strides. The loss and recovery of the center of gravity causes the gait to be performed more quickly so that the individual does not fall ${ }^{23}$.

Arantes et al. ${ }^{24}$ noted in their study that, elderly women in strength training showed double support time less than the elderly women practicing water aerobics. Thus, the muscle strength of lower limbs is an essential factor to reduce or prevent the increased double support with aging. In addition, the single support found to be smaller, due to the increased muscle strength and, consequently, due to the higher average linear velocity of the gait.

The results found in this study are relevant to clinical practice because of the growing number of falls evidenced by Beauchamp et al. ${ }^{25}$ in the elderly population and with chronic diseases. It is suggested that the professionals involved in the rehabilitation of individuals with COPD are aware of that the training of functional activities must be carried out progressively, so that during gait performance, the CG recovery occurs quickly and efficiently, avoiding the risk of falls and thus improving the targeting of rehabilitation.

As a limitation of the study, we highlight the absence of a control group. The lack of literature with this approach in this clinical condition draws attention to the need for studies focusing on the effect of therapy in recovery/maintenance of the gait functionality of these participants.

\section{CONCLUSION}

The physical effort influenced the gait pattern and cardiorespiratory parameters in this group of individuals with COPD. During the post-test, we observed an increased sensation of dyspnea, increased speed, increase in the first peak of the ground reaction force and reduction in the force trough used, reduction in the first double support time and first peak force time. So, the increase in gait speed and the reduction in damping time of the foot's impact on the ground after the physical effort may increase the risk of falls. It is suggested that, in clinical practice, functional activities are conducted progressively, so that during the gait performance, the $\mathrm{CG}$ is restored quickly and efficiently making the ambulation safer. 


\section{REFERENCES}

1. Rabe KF, Hurd S, Anzueto A, Barnes PJ, Buist AS, et al. Global Initiative for Chronic Obstructive Lung Disease. Global strategy for the diagnosis, management, and prevention of chronic obstructive pulmonary disease: GOLD executive summary. Am J Respir Crit Care Med. 2007;:776(6):532-55.

2. Dourado VZ, Antunes LCO, de Carvalho LR, Godoy I. Influência de características gerais na qualidade de vida de pacientes com doença pulmonar obstrutiva crônica. J Bras Pneumol. 2004;30(2):207-14.

3. Langer D, Probst VS, Pitta F, Burtin C, Hendrinks E, Schans CPVD, et al. Guia para prática clínica: Fisioterapia em pacientes com Doença Pulmonar Obstrutiva Crônica (DPOC). Rev Bras Fisioter. 2009:13(3):183-204.

4. Trevisan ME, Porto AS, Pinheiro TM. Influência do treinamento da musculatura respiratória e de membros inferiores no desempenho funcional de indivíduos com DPOC. Fisiot Pesq. 2010;17(3):209-13.

5. Velloso M, Jardim JR. Funcionalidade do paciente com doença pulmonar obstrutiva crônica e técnicas de conservação de energia. J Bras Pneumol. 2006;32(6):580-6.

6. Ferreira SA, Guimarães M, Taveira N. Reabilitação respiratória na DPOC: do treinamento de exercício para a "vida real". J Bras Pneumol. 2009;35(11):1112-5.

7. Dourado VZ, Tanni SE, Vale SA. Manifestações sistêmicas na doença pulmonar obstrutiva crônica. J Bras Pneumol. 2006;32(2):161-71.

8. Ribeiro A, Wayhs JHA, Machado MM, Fleig TCM, Silva ALG. Análise da marcha em portadores de doença pulmonar obstrutiva crônica. Fisioter Mov. 2011:24(2):211-9.

9. Farinatti PTV, Lopes LNC. Amplitude e cadência do passo e componentes da aptidão muscular em idosos: um estudo correlacional multivariado. Rev Bras Med Esporte. 2004:10(5):389-94.

10. Ribas DIR, Israel VL, Manfra EF, Araújo CC. Estudo comparativo dos parâmetros angulares da marcha humana em ambiente aquático e terrestre em indivíduos hígidos e adultos jovens. Rev Bras Med Esporte. 2007:13(6):371-5,

11. Sousa DSS, Tavares JMRS, Correia EM, Mendes E. Análise clínica da marcha exemplo de aplicação em laboratório de movimento. Anais do 20 Encontro Nacional de Biomecânica; 8-9 de fevereiro 2007; Évora, Portugal. Porto, U.Porto; 2008.

12. Derom E, Marchand E, Troosters T. Pulmonary rehabilitation in chronic obstructive pulmonary disease. Ann Readapt Med Phys. 2007:50:615-26.
13. Ortiz CAL. Classificação da força de reação do solo durante a marcha de sujeitos com fratura de membro inferior (dissertação). Rio de janeiro: Universidade Federal do Rio de Janeiro; 2010.

14. Rosa FW, Camelier A, Mayer A, Jardim JR. Avaliação da capacidade de exercício em portadores de doença pulmonar obstrutiva crônica: comparação do teste de caminhada com carga progressiva com o teste de caminhada com acompanhamento. J Bras Pneumol. 2006:32(2):106-13.

15. Bekkering GE, Hendriks HJM, Chadwick-Straver RVM, Gosselink $\mathrm{R}$, Jongmans M, Paterson WJ, et al. Clinical practice guidelines for physical therapy in patients with chronic obstructive pulmonary disease. Royal Dutch Socielty for Physical Therapy. KNGF. 2003;3:1-41.

16. Singh SJ, Morgan MD, Scott S, Walters D, Hardman AE. Development of a shuttle walking test of disability in patients with chronic airways obstruction. Thorax. 1992;47(12):1019-24.

17. da Cunha-Filho IT, Pereira DAG, de Carvalho AMB, Campedeli L, Soares M, Freitas JS. Confiabilidade de testes de caminhada em pacientes claudicantes: estudo piloto. J Vasc Bras. 2008;7(2):106-11.

18. Pessoa BV, Jamami M, Basso RP, Regueiro EMG, Di Lorenzo VAP, Costa $D$. Teste do degrau e teste da cadeira: comportamento das respostas metábolo-ventilatórias e cardiovasculares na DPOC. Fisioter. Mov. 2012;25(1):105-15.

19. Cordoni PK, Berton DC, Squassoni SD, Scuarcialupi MEA, Neder JA, Fiss E. Comportamento da hiperinsuflação dinâmica em teste em esteira rolante em pacientes com DPOC moderada a grave. J Bras Pneumol. 2012;38(1):13-23

20. Yentes JM, Sayles H, Meza J, Mannino DM, Rennard SI, Stergioua N. Walking abnormalities are associated with COPD: An investigation of the NHANES III dataset. Respiratory Medicine, 2011;105(1):80-7.

21. Cook TM, Farrell K, Carey IA, Gibbs JM, Wiger GE. Effects of restricted knee flexion and walking speed on the vertical ground reaction force during gait. J Orthop Sports Phys. 1997;25(4):236-44.

22. Perry J. Análise da marcha: marcha normal Barueri, SP: Malone; 2005.

23. Iwabe C, Diz MAR, Barudy DP. Análise cinemática da marcha em indivíduos com Acidente Vascular Encefálico. Rev Neurocienc. 2008;16(4):292-6

24. Arantes L, Coelho F, Silva P, Costa G, Gobbi LTB. Caracterização dos parâmetros temporo-espaciais da marcha em idosas praticantes de diferentes modalidades de exercícios. Revista Movimenta, 2009;2(1):7-11.

25. Beauchamp MK, Hill K, Goldstein RS, Janaudis-Ferreira T, Brooks D. Impairments in balance discriminate fallers from non-fallers in COPD. Respiratory Medicine. 2009; 103(12):1885-91. 